\title{
Sedimentological distinction in glacigenic sediments between load casts induced by periglacial processes from those induced by seismic shocks
}

\author{
A.J. (Tom) VAN LOON ${ }^{1, *}$, Małgorzata PISARSKA-JAMRO $\mathrm{Y}^{2}$ and Barbara WORONKO ${ }^{3}$ \\ 1 Shandong University of Science and Technology, College of Science and Engineering, Qingdao 266590, China \\ 2 Adam Mickiewicz University, Institute of Geology, B. Krygowskiego 12, 61-680 Poznań, Poland \\ 3 University of Warsaw, Faculty of Geology, wirki i Wigury 93, 02-089 Warszawa, Poland
}

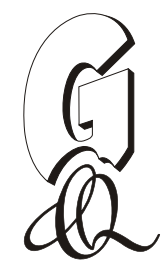

Van Loon, A.J. (Tom), Pisarska-Jamro y, M., Woronko, B., 2020. Sedimentological distinction in glacigenic sediments between load casts induced by periglacial processes from those induced by seismic shocks. Geological Quarterly, 64 (3): 626-640, doi: 10.7306/gq.1546

\begin{abstract}
Loading processes and the resulting load structures induced by processes related to periglacial conditions are compared to those induced by seismic shocks. The load structures themselves are relatively easily recognizable but the responsible trigger mechanism is, though depending on the geological context, commonly difficult to establish. Load structures like load casts, pseudonodules, ball-and-pillow structures and flame structures are commonly ascribed to instable density gradients within sediments and to differential loading, but their formation always requires liquefaction. In glacigenic sediments, deformation structures have most commonly been ascribed to periglacial processes (as a type of cryoturbations), but it becomes ever more clear that glacigenic sediments can, particularly during ice-front fluctuations, be affected by faulting-related earthquakes (due to glacio-isostatic adjustment), and the thus triggered seismic shocks may result in deformations, including most commonly - load structures. We inventory the evidence that may help to distinguish, on the basis of textural and structural features, load structures with a seismic origin from those that result from periglacial processes, taking into account that truly diagnostic criteria do not exist.
\end{abstract}

Key words: load casts, pseudonodules, soft-sediment deformation structures, cryoturbation, seismites.

INTRODUCTION

Load casts and genetically associated structures (particularly pseudonodules and flame structures) are the most common type of soft-sediment deformation structures (SSDS). The reason is that numerous processes may trigger loading, particularly in sediments that are partly consolidated but that still contain a significant amount of pore water. This variety of possible triggers hampers the interpretation. Yet, analysis of the triggering mechanism of SSDS has been recognized as an important tool for the interpretation of the conditions that prevailed during or shortly after deposition of the sediments under study.

The interpretation of load structures in unconsolidated, glacigenic sediments poses commonly a major problem since, in addition to possible other - more common - triggers, two entirely different processes may be responsible for the triggering of these structures. The first trigger is the occurrence of periglacial processes, which affect sediments in a wide zone in front of an ice sheet, whether advancing, stable or retreating. The second trigger is seismic activity, which is common in areas

\footnotetext{
* Corresponding author, e-mail: Geocom.VanLoon@gmail.com Received: February 17, 2020; accepted: June 19, 2020; first published online: August 18, 2020
}

with periglacial conditions because of the changing differential pressure exerted by the weight of the advancing or retreating land-ice sheet on the earth crust, resulting in subsidence during ice advance and in uplift during ice retreat. Particularly the glacio-isostatic adjustment of the earth crust tends to take place step-wise, resulting in earthquakes that may have a sufficiently large magnitude to trigger liquefaction ( $\mathrm{M} \geq 4.5$ : Marco and Agnon, 1995) that may strongly deform susceptible sediment layers near the earth surface.

Recognition of periglacial conditions or seismic activity that affected sediments under study can be of great importance for a proper interpretation of the tectonic, sedimentary, climatological and morphological conditions of the area. The correct recognition of a periglacial or a seismic origin of load structures is significantly hampered, however, by an unfortunate heritage: glacigenic sediments have initially been investigated for more than a century almost exclusively by physical geographers, in a timespan that little was known about SSDS, and nothing at all about the role that seismicity may play in it. Consequently, all SSDS encountered in glacigenic sediments were for a long time attributed to periglacial processes. Even nowadays this is reflected in the sometimes mutually contradictory viewpoints of Quaternary geologists regarding SSDS. Load casting, for instance, is - according to Brigitte Van Vliet-Lanoë (pers. comm., 2018) - “...exceptional in periglacial conditions [as I deduce] from 40 years of Arctic experience in stable and unstable seismic zones. I never found a clear example of load cast induced by frost activity...". In 
contrast, Jef Vandenberghe (pers. comm., 2018) states: "In a review of periglacial loading you cannot 'forget' the classical literature by ... As concerns the origin of the reverse gradient and the fluidization [sic!] of the deformed sediment that is needed in periglacial loading, reference should be made to...[sic!]". These statements make clear that Quaternary geologists still adhere strongly contradictory views regarding SSDS, indicating how badly needed contributions like the present one are, even if they may raise severe criticism.

True interest of geologists in unconsolidated Quaternary sediments came only in the past few decades, and they tended initially to accept conclusions reached during earlier research. Geological studies of the Quaternary (mostly aimed at sedimentological aspects) thus started with ascribing SSDS in glacigenic sediments to periglacial processes (which were at the time still hardly studied by geologists).

When the sedimentological study of Quaternary sediments progressed, the unavoidable conclusion was eventually reached that many SSDS in these sediments should not be ascribed to periglacial processes, partly because it was frequently found that alternations of strongly deformed and non-deformed occur in many successions, also at places where neither such frequent alternations of periglacial and "warm" time-spans, nor seasonal alternations could be held responsible. In combination with the increasing knowledge about SSDS that were triggered by other processes, it became clear that the long-time prevailing explanations of SSDS in glacigenic sediments should be reviewed critically.

It was also realized, however, that many SSDS are formed by a combination of processes, and that SSDS may become deformed themselves again by later processes. This raised during many investigations the question of whether a specific deformation structure in a glacigenic succession had been formed by, for instance, glaciotectonics, periglacial processes, seismic activity, "normal" syn- or post-depositional deformation processes, or by a combination of them, acting at the same time or successively.

The more abundant a specific type of SSDS is, the more frequently this question came up. It is therefore not surprising that many discussions concerned load structures, as these are the most common in many types of deposit. The question of how to distinguish between load structures formed by different processes has consequently been raised often, but satisfactory and commonly accepted answers have not been given as yet. In the present contribution, we aim at doing so for load structures formed by periglacial processes and load structures formed due to seismic activity. We are fully aware that load casts can be formed under entirely different conditions and by numerous different processes as discussed extensively in a special issue of Sedimentary Geology devoted to SSDS (Moretti et al., 2016), but we restrict ourselves to the just-mentioned two types, as such a distinction, which is already fairly difficult, might be considered as a first step into the direction of establishing criteria (or evidence) that may help to distinguish between all possible triggers and mechanisms that may result in load structures. Moreover, the Pleistocene sediments developed under periglacial conditions were, as explained above, frequently affected by earthquakes, so that particularly for these sediments it is desirable to distinguish which of the two most likely processes (a seismic shock or periglacial processes) must be held responsible for the presence of load structures. Most of SSDS examples shown in the present contribution have been interpreted already in terms of their trigger mechanism (see the captions of these figures), and we refer the reader to these publications.
The present contribution has the following two main objectives:

- investigating whether differences exist between load structures developed due to a periglacial setting and those developed due to seismic activity,

- answering the directly related question of whether it is possible to determine whether specific load structures have been caused by periglacial or by seismic processes, based on their characteristics in combination with their specific sedimentary setting.

\section{LOAD STRUCTURES}

Load structures, and more particularly load casts, belong to the first structures recognized as a result of deformation of unconsolidated sediments. The first clear descriptions came from Macar (1948), who investigated Devonian sediments in the Belgian Ardennes where he discovered pseudonodules, for which he introduced this new term (in the form of "pseudo-nodules" to make clear that these structures look like concretions - nodules in French - but have a different origin). His studies received not much attention, but were used by Van Straaten (1954), who compared the pertinent sediments with those of the present-day Dutch tidal flats of the Wadden Sea, and who came to the conclusion that the sedimentary features (including structures) in ancient sediments should be interpreted on the basis of processes that act in modern equivalents. This study by Van Straaten, which received much international attention, was a break-through for the interpretation of ancient sediments on the basis of modern equivalents. Only a few years after Macar's discovery - and sedimentary recognition of pseudonodules Kuenen (1953) introduced, in a study related to the sole marks of turbidites, the term "load cast" for the SSDS that had earlier (incorrectly) been described by Shrock (1948) as "flow cast".

A commonly accepted explanation for the origin of load casts came from D ułyński (1966) and Anketell et al. (1969, 1970), who made clear that reversed density gradients (commonly between muds and overlying sands) must be responsible: just by gravity, the denser sand sinks locally in the water-saturated mud. However correct this explanation may be, it left several questions: why does the sinking take place only locally, why do not all sandy sediments overlying muddy ones show load casts, and why does not the entire sandy layer sink down in the mud? Some questions have been answered satisfactorily in the meantime on the basis of studies regarding liquefaction (an incorrect term: the sediment does not behave as a fluid but as a plastic mass!) and fluidization. It has also become clear, however, that in many cases a trigger must have initiated the loading process. And it is the unravelling of the trigger that nowadays is the main problem, certainly in glacigenic sediments.

This unravelling of the trigger requires a good insight into the process involved in loading, as well as in the characteristics of the resulting load structures. Therefore we pay first some attention to these aspects, including the related terms, as these are frequently used incorrectly in the literature, which highly contributes to misunderstanding about the genesis of these SSDS.

\section{LOADING PROCESS}

Unravelling the trigger that initiated loading requires insight into the loading process, which itself depends largely on sediment properties. As mentioned above, the most common gene- 
sis of load structures is gravity-induced sinking of part of a sediment layer into the underlying layer due to a reversed density gradient. This has been confirmed by numerous studies of SSDS in periglacially affected areas (see, among others, Murton and French, 1993; French, 2007; Vandenberghe, 2009, 2013; Superson et al., 2010; Alexeev et al., 2014), as well as for seismically affected sediments (see, among others, Obermeier, 1996; Lafuente et al., 2008; Van Loon et al., 2016). It became also clear already some decades ago why sandy layers do not sink as an entity in an underlying mud layer: any perturbations at the interface between the overlying, denser sediment and the underlying less dense sediment act as Rayleigh-Tayler instabilities, causing irregularities to amplify until a gravity-driven vertical movement is locally achieved. It is also clear why a loading process stops at a certain moment: the underlying layer is pressed down and the vertical pressure forces pore water to flow out sideward, which implies consolidation of the underlying mud. This increases its resistance, and when the resistance equals the gravitational force, the process stops.

Load structures that are formed in this way result as a rule from conditions and processes that are inherent to the depositional environment such as the deposition of sandy turbidites on fine-grained sediments in front of a delta (which is known from numerous field data), or such as might be expected from the freezing/thawing alternations which occur particularly under periglacial conditions. Load casts can, however, also be formed due to external factors such as passing shock waves resulting from seismic activity. The group of deformation structures created by periglacial processes, mostly differential frost heave resulting in differential accumulation of segregated ice in the soil following their grain-size distribution, are commonly jointly called "cryoturbations" (see Edelman et al., 1936), whereas layers that are completely deformed as a result of seismic activity, while intercalated between (in principle) non-deformed layers are called "seismites" (e.g., Seilacher, 1984; Van Loon, 2014). We restrict ourselves in the following, unless stated otherwise, to these two categories.

\section{TERMINOLOGY}

Simple loading processes produce simple load structures. The most simple is the local sinking of a sand mass, resulting in a bent, concave-upward contact plane between the mud and the sinking sand. If this process continues, a ball shaped sand body develops (Fig. 1A), with its upper side parts still connected to the parent sandy layer. If the sand sinks deeper, it will gradually lose its contact with the parent layer (Fig. 1B) and eventually it may even become completely separated from its parent layer and form a sandy ball (with its internal laminations more or less parallel to its outer boundaries). Such an isolated ball is called "pseudonodule" (Fig. 1C). Only in exceptional cases, for instance when "new" sand is continuously supplied to the depression that is formed at the sedimentary surface, while simultaneously water is expelled easily from the over-saturated underlying mud, a vertical sandy body may develop (Fig. 2), which eventually leads to faulting along its sides, causing a complex faults-bound structure (Fig. 3) that is known as gravifossum (Van Loon and Wiggers, 1976).

It is also possible that a sand layer forms load casts in an underlying sand layer, if there is a sufficient difference in water content and/or grain size. The thus formed load structures are called ball-and-pillow structures (Fig. 4). Since these fairly exceptional types are not truly relevant for the distinction between periglacial and seismic load structures, we will not deal with these types in the following. When a sand body sinks into the
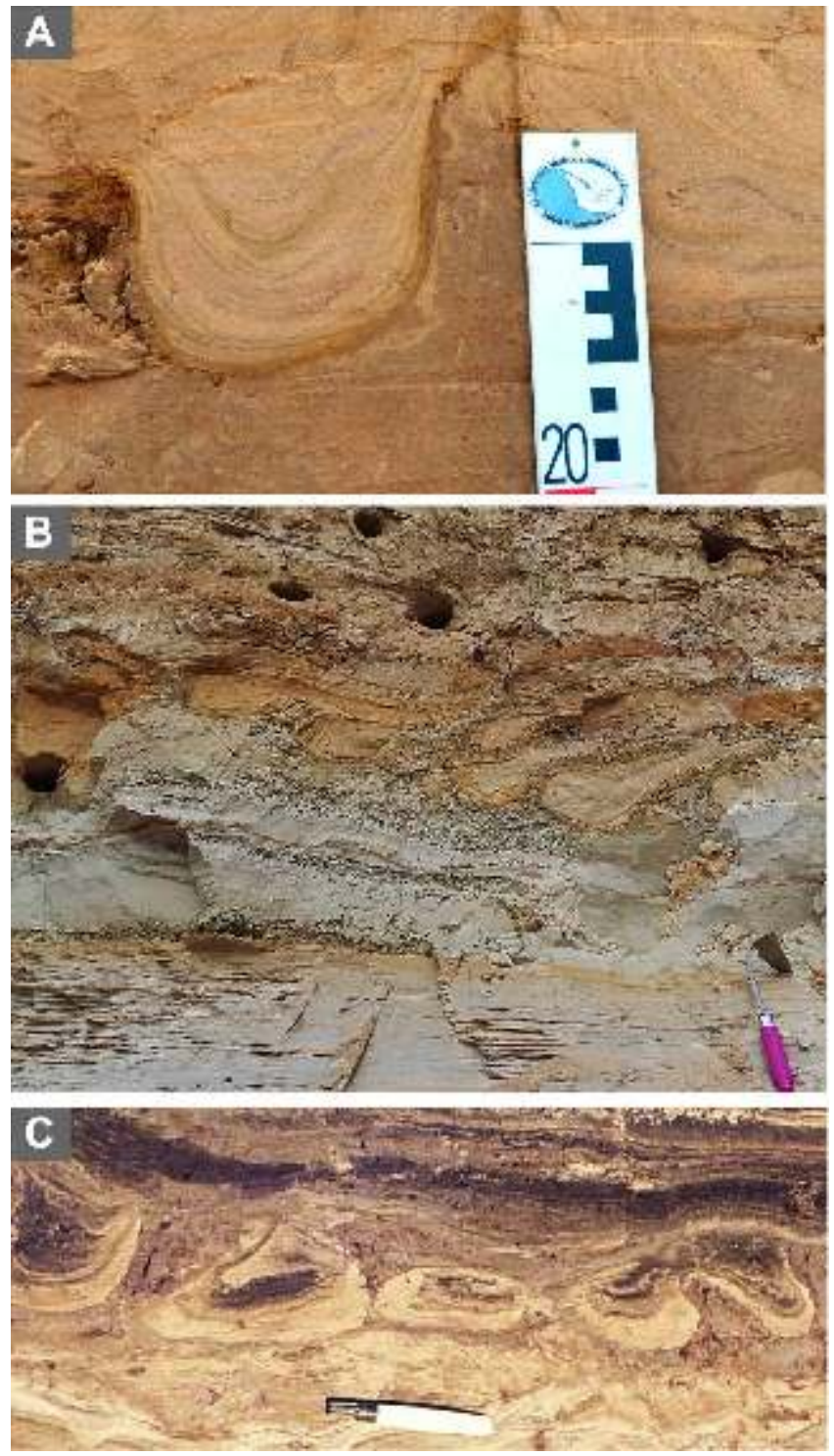

Fig. 1. Load casts

A - simple load cast, formed by the local sinking of sand into the underlying liquefied mud; note the lamination in the load cast parallel to its outer boundary; load cast of periglacial origin, Valmiera, N Latvia; B - periglacially formed load structure developed into a stage intermediate between a load cast and a pseudonodule; the loaded mass is still slightly connected to the parent layer; Rechitsa site, Belarus (see also Marks et al., 2018); C - pseudonodules; the sunk sandy "balls" have no longer contact with the parent layer, which has completely been "consumed" by the load casts; note the internal lamination parallel to the outer boundary of the structures; lagooal subrecent sediments in a reclaimed area in the central Netherlands

underlying mud, a space problem is created in the mud. This is compensated by upward push of the mud alongside the sunken sand mass. Particularly if a series of load casts is developed fairly close together (which increases the space problem), the mud that is pressed upwards between the load casts forms flame-like structures (Fig. 5A), which are consequently called "flame structures". Because this process tends to take place while the sediment is slightly consolidated and thus behaves in a plastic way, the flames still show their original (though deformed) internal structures (commonly lamination). They commonly do not pierce the overlying sand layer (Fig. 5B), but may 


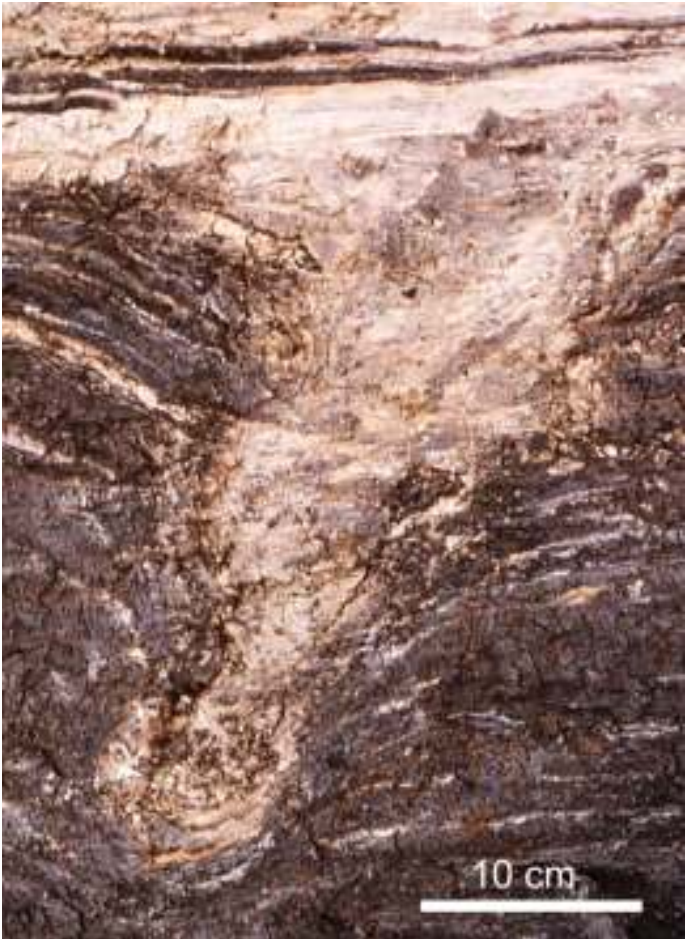

Fig. 2. Deeply sunk load cast (see boundary-parallel lamination in the bottom part) with a large vertical extent that could develop because some sandy material sank in water-saturated silt, leaving a depression at the sedimentary surface in which new sand was deposited, causing a "chain reaction" of sandy infilling and further loading; Holocene lagoonal sediments, central Netherlands

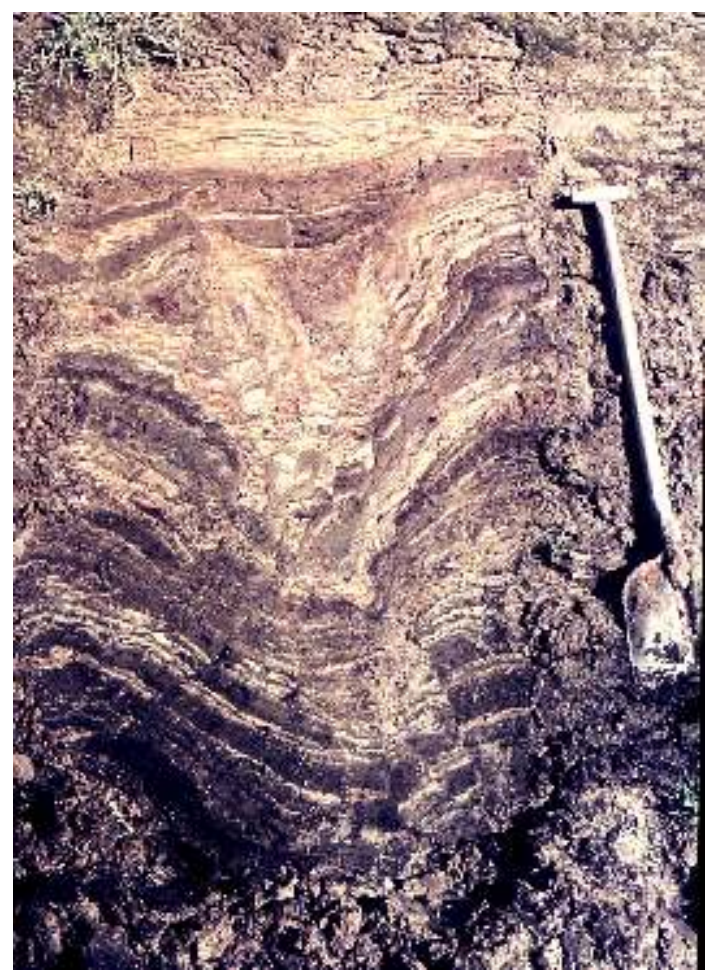

Fig. 3. Gravifossum in Holocene lagoonal sediments (central Netherlands), developed as an extreme result of loading

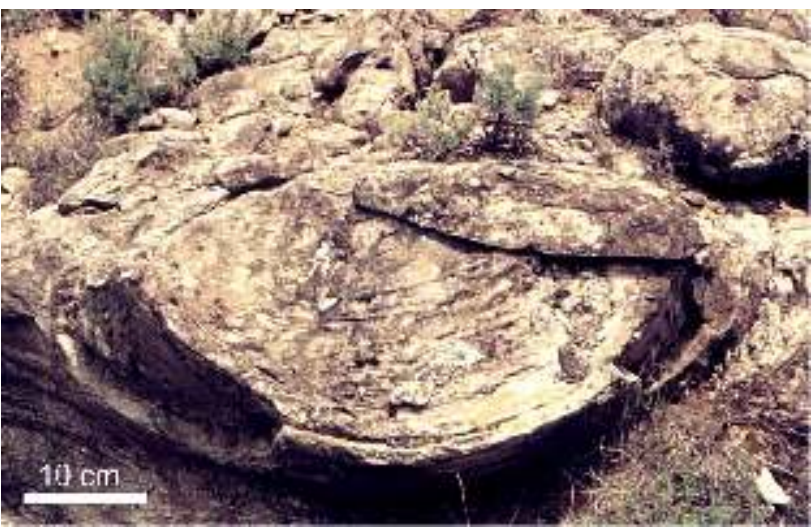

Fig. 4. Ball-and-pillow structure formed by the loading of a thick, probably quickly deposited, sandy layer into underlying water-saturated sands; Cuisian/Lutetian Perarrua Formation near Bellestar (Spain)

do so when the loading process is repeated. This is a fundamental difference with injection structures (Fig. 5C), which develop while in fluidized state (and which consequently do no longer show original internal structures), and which clearly form bodies that intrude the overlying sediments, cutting off internal structures. In exceptional cases, however, flame structures may be pressed upwards so far that they partly penetrate the overlying layers, cutting of structures. Even in that case they can be distinguished from injection structures, however, because their internal structures are still preserved.

\section{THE NON-DIAGNOSTIC MORPHOLOGY OF LOAD STRUCTURES}

The morphology of load structures such as load casts, pseudonodules, and ball-and-pillow structures, and of genetically associated structures such as flame structures, depends largely on the initial sedimentary setting, the driving force and the duration of the deformable state, whereas the nature of the trigger mechanism seems to play a minor or even negligible role (Vandenberghe, 2009; Owen and Moretti, 2011; Owen et al., 2011). A major problem is that load structures with identical or almost identical characteristics (size, outer shape, internal structure, etc.) can be triggered by a variety of processes, whereas loading caused by the same trigger mechanism can result in load casts with different size, shape and internal structure, depending on the grain-size distribution, thickness of laminae, duration of the loading process, etc. (Van Vliet-Lanoë et al., 2004; Van Loon, 2014; Vandenberghe et al., 2016, 2017).

Furthermore, overprinting is not exceptional: for instance, periglacially-deformed sediments can be deformed once more by seismic activity, and vice versa (e.g., Alexeev et al., 2014; Vandenberghe et al., 2016). This is of particular interest because it was found in the past few decades that numerous load structures in Quaternary sediments should be ascribed to the rather frequent earthquakes that were triggered by shock-wise isostatic adjustment of the earth crust during the retreat of an ice sheet (e.g., Mörner, 1990, 1991; Wu and Johnson, 2000; Van Vliet-Lanoë et al., 2004; Hoffmann and Reicherter, 2012; Brandes et al., 2012; Van Loon and Pisarska-Jamro y, 2014; Pisarska-Jamro y et al., 2018a; Pisarska-Jamro y and Woźniak, 2019) or during advance of an ice sheet (Pisarska-Jamro y et al., 2018a, 2019a, b). 

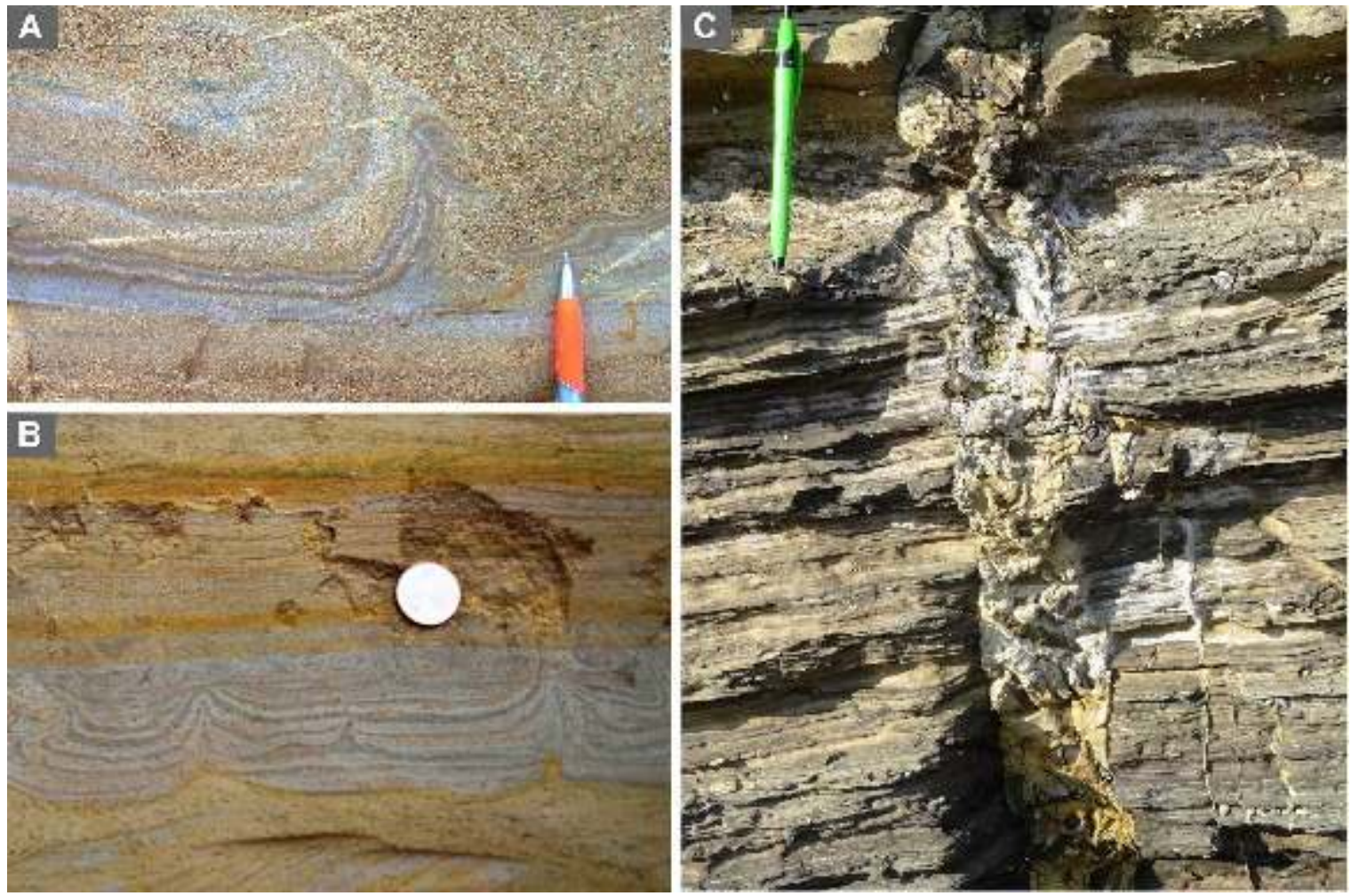

Fig. 5. Flame structures

A - flame structure in Weichselian glaciofluvial sands in a quarry near Kärne (S Sweden); note the preserved lamination, which was deformed while being pushed up between the two sinking load casts; the preserved laminae, which prove a liquefied state during deformation, follow the outer boundaries of the adjoining load casts; B - various stages in the development of flame structures; note how the lamination in the load casts and the flames tend to run parallel; Valmiera, N. Latvia; C - injection structure in the form of a clastic dyke, perpendicular to the bedding. Note that no internal lamination or other primary structure is preserved in the dyke, due to fluidization; Cretaceous Gyeokpori Formation, SW South Korea

Consequently, it is commonly recommended not to assign a specific origin to SSDS as those under study here without detailed analysis of the characteristics of both the structure itself and its geological context (e.g., Seilacher, 1984; Vandenberghe and Van den Broek, 1982; Van Vliet-Lanoë et al., 2004; Ogino and Matsuoka, 2007; Van Loon, 2009, 2014; Van Loon and Maulik, 2011).

\section{LOADING IN PERIGLACIAL AND SEISMIC SETTINGS}

Loading occurs in almost all depositional environments, but is particularly common in water-saturated sediments with a relatively high silt content (Moretti et al., 1999), for instance in lacustrine, fine-grained fluvial and deltaic sediments (including their glaciogenic counterparts), but occurs also in marine and terrestrial coarser-grained deposits (Deev et al., 2009; Koç Taşgin and Türkmen, 2009; Rana et al., 2016; Vandenberghe et al., 2016).

\section{LOADING UNDER PERIGLACIAL CONDITIONS}

Periglacially-induced loading is restricted to the thickness of the thawed layer (the so-called active layer) during the degradation of the ground ice in near-surface sediments, which is the sedimentary succession, from the sedimentary surface downwards, that thaws in the warm season, while being frozen and forming part of the permafrost during the cold season. The active layer, which consequently has different thicknesses from year to year (depending on the temperature and the duration of the "warm" season) consists, as a rule, not of a specific layer but may comprise several layers; it maintains each year over long distances a more or less similar thickness, depending on the topography, snow cover, slope orientation, vegetation, drainage, water content and lithology (French, 2007; French and Shur, 2010). This implies that the active layer is not necessarily bound to specific layers but may, for instance in the case of a glacitectonically tilted sediment, cross-cut one or more sedimentary layers. This is, as will be detailed below, a characteristic that is of prime importance when distinguishing between a periglacial and a seismic trigger for the formation of SSDS in periglacial sediments

Loading can develop under periglacial conditions due to (1) cryohydrostatic flow (high pore pressure), (2) cryostatic heave (freezing-induced pressure), and (3) like under all climatic conditions, liquefaction due to any trigger that affects water-saturated sediments with a reversed density gradient (Vandenberghe, 2013). In the first case, the deformation structures develop as a result of lateral movement of unfrozen water trapped between two impermeable layers: the underlying sediments (due to the permafrost table) and the overlying sediments (due to the downward freezing front; French and Shur, 2010). In the second case, the pressure in frozen sediment can cause load- 
ing by volumetric expansion of freezing water and by differential frost penetration caused by ice segregation (Van Vliet-Lanoë, 1991; Vandenberghe, 2013). The third main process responsible for loading under periglacial conditions is based on the presence of reversed density gradients in the sediments in the water-saturated thawing zone above a still frozen subsoil (e.g., Murton and French, 1993; Harris et al., 2000; French et al., 2005; Vandenberghe, 2013), occasionally resulting in irregular load casts due to thawing of the only partially molten nature of the soil during the loading process (Fig. 6). The degradation of ice-rich permafrost can also cause loading due to the ice-rich upper layer of the permafrost, which results in a decreasing density of the sediments in comparison to the overlying layers (French, 2007). Other favourable conditions for periglacial loading are moist, low-lying, flat, non-drained areas such as small depressions with fine-grained sediments or with a buried permafrost table (Vandenberghe, 2013). Konrad (2005) suggested that deformation structures may also originate from ice-lens formation and surface heave, which are common processes in the periglacial environment.

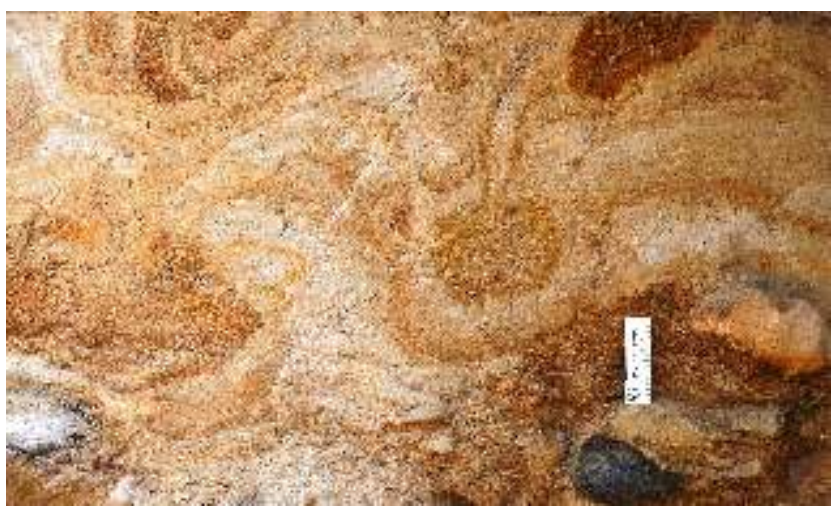

Fig. 6. Irregular load cast formed probably due to a reversed density gradient in still partly frozen glaciofluvial sediments during season-bound melting of the uppermost sediments in a periglacial setting; Wrocław (Haller Street), SW Poland

\section{LOADING TRIGGERED \\ BY A SEISMIC SHOCK}

Seismically-induced loading is caused by seismically-induced S-waves travelling through water-saturated, unconsolidated sediments (Rossetti, 1999). The maximum reported depth of seismically-induced liquefaction is $10 \mathrm{~m}$, but most liquefaction is restricted to depths of $<5 \mathrm{~m}$ below the sedimentary surface/palaeosurface (Obermeier, 1996), commonly even to the uppermost decimetres. The deeper sediments are buried, the closer the packing of grains becomes, and the worse the condition is for the loss of shear strength, hampering liquefaction. Seismically-induced loading is largely controlled by the lithology (Lafuente et al., 2008), the density and viscosity of the sediment, the overpressure time, and the distance of the sediment to the epicentre. Allen (1986), Ambraseys (1988) and Galli (2000) state that liquefaction is unlikely to develop loading in the case of earthquakes with a magnitude of $<5$, but Marco and Agnon (1995) calculated a minimum magnitude of 4.5 for starting liquefaction. Most high-magnitude earthquakes are followed by aftershocks, which also may have magnitudes that are sufficient to transform previously undisturbed sediment layers into seismites.
A complicating factor is that the aftershocks can also deform previously deformed sediments, causing, for instance, successive phases of loading; this is expressed in the form of load casts that sink into previously formed load casts (i.e., multi-phase load casts: Fig. 7), examples of which are shown by Van Loon and Pisarska-Jamro y (2014) and Van Loon et al. (2016).

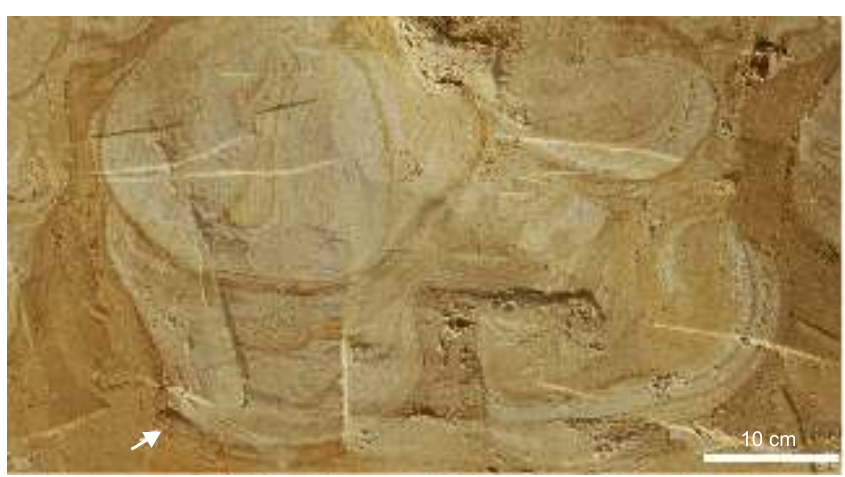

Fig. 7. Multi-phase load casts, showing load casts within load casts

This is due to successive earthquakes that caused a series of seis mic shocks of sufficient strength to deform already earlier deformed glaciolacustrine silty sediments in a seismite, Siekierki, NW Poland (detail of a photo in Van Loon and Pisarska-Jamro y, 2014)

\section{DIFFERENCES BETWEEN PERIGLACIALLY- AND SEISMICALLY-INDUCED LOAD STRUCTURES}

Interpretation of the genesis of load structures requires, following the great majority of researchers, particular attention for the following aspects:

- setting of the study area (seismically active region, extent of the periglacial zone, extent of glaciations, relief, etc.);

- lithology of the sediments involved in the SSDS;

- position of the deformed sediments within the sedimentary succession (Owen et al., 2011; Moretti and Van Loon, 2014; Belzyt and Pisarska-Jamro y, 2017; Pisarska-Jamro y et al., 2019a).

Even taking the above aspects into account, it seems commonly impossible to find definite proof for a seismic or a periglacial origin of a load structure. Distinction might rather be achieved on the basis of circumstantial evidence. Extensive field investigations of both periglacially affected and seismically affected Quaternary sediments have led us to the conclusion that only detailed sedimentological analyses of the textural and structural characteristics of the structures involved, in combination with analysis of the immediately surrounding sediments and of the entire sedimentary succession, may provide strong evidence for either origin.

We have found that the following aspects constitute in practice the best tools for such a distinction:

- vertical distribution of the load structures (see Vertical distribution of the load structures),

- horizontal distribution of the load structures (see Horizontal distribution of the load structures),

- the internal structure of the load structures (see Internal structure of load structures). 


\section{VERTICAL DISTRIBUTION \\ OF THE LOAD STRUCTURES}

The most important characteristic of seismites is that the SSDS are restricted to a single, well-defined layer (Fig. 8A; occasionally a set of a few layers) with distinct boundaries with the under- and overlying layers that have not been deformed by the seismic shock (e.g., Van Loon et al., 2016; Morsilli et al., 2020). A straight, undeformed truncation level of the top of such deformed layers, as occasionally observed, particularly in shallow lacustrine successions, indicates that deformation structures must have developed during a single seismic time-span (though possibly during a shock followed by aftershocks).

Periglacial processes, in contrast, affect sediments to a certain depth (determined by the thickness of the active layer; Fig. 8B), so that load casts and related SSDS can extend through the sediments without being restricted to specific layers. Particularly in the case of somewhat tilted sediments (for instance due to glaciotectonics), this may lead to load structures that reach a specific topographic depth, represented by a level which cross-cuts sedimentary layers. Even if sedimentation continues at such a place, this layer-crossing character of the level with load structures forms strong evidence - if not proof of a periglacial origin.

The thickness of a seismite determines, among other things, the maximum vertical size of the SSDS (Fig. 9A). Such a size restriction is less outspoken in periglacially affected sediments, because deformation structures, including load structures, can develop throughout the vertical extent of the active layer independently from its thickness (Fig. 9B). If the active layer consists of a sedimentary succession composed of a few sandy layers intercalated by silty layers, loading may start in the warm season at each boundary between a sandy and an underlying silty layer, so that various layers with load structures will originate. Because the active layer can operate in a periglacial setting during many years (even tens of thousands of years), this might eventually result in the development of a thick sedimentary succession with very complicated SSDS (Fig. 8B), but - in contrast to seismites - the load structures will not be restricted to specific layers with well defines lower and upper boundaries. Load casts and pseudonodules may also occur at different depths in a seismite (Fig. 9C), probably because of inhomogeneities in the deformed layer(s), but their distribution is always clearly restricted to a specific layer or set of layers.

Considering the above differences between periglaciallyand seismically-triggered load structures, distinction between these two groups might be facilitated by the following aspects regarding their vertical distribution in the deformed sediments:

- load structures restricted to a single level that also shows many other SSDS are most commonly seismic, whereas such structures crossing boundaries with non-deformed or differently deformed layers are most commonly periglacial;
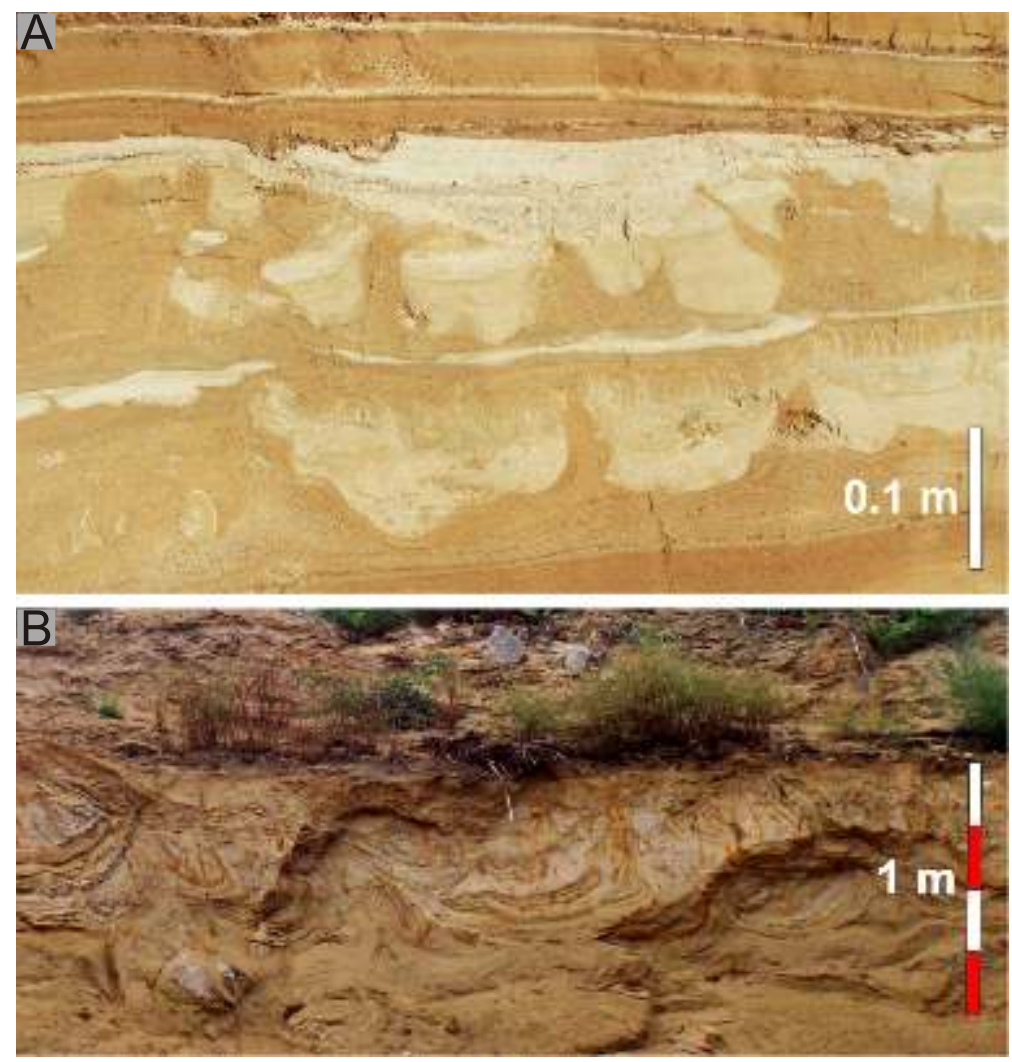

Fig. 8. Distribution of deformation structures in a sedimentary succession

A - two laterally continuously strongly deformed silty/sandy seismites, separated from each other by a thin undeformed sandy level, with under- and overlying non-deformed glaciolacustrine sediments, Rakuti, Latvia; B - periglacially deformed, partly loaded, sediments with deformation structures that are not restricted to a well-defined layer; sand quarry at Ryssjön, S Sweden (detail of a photo in Gruszka et al., 2016) 

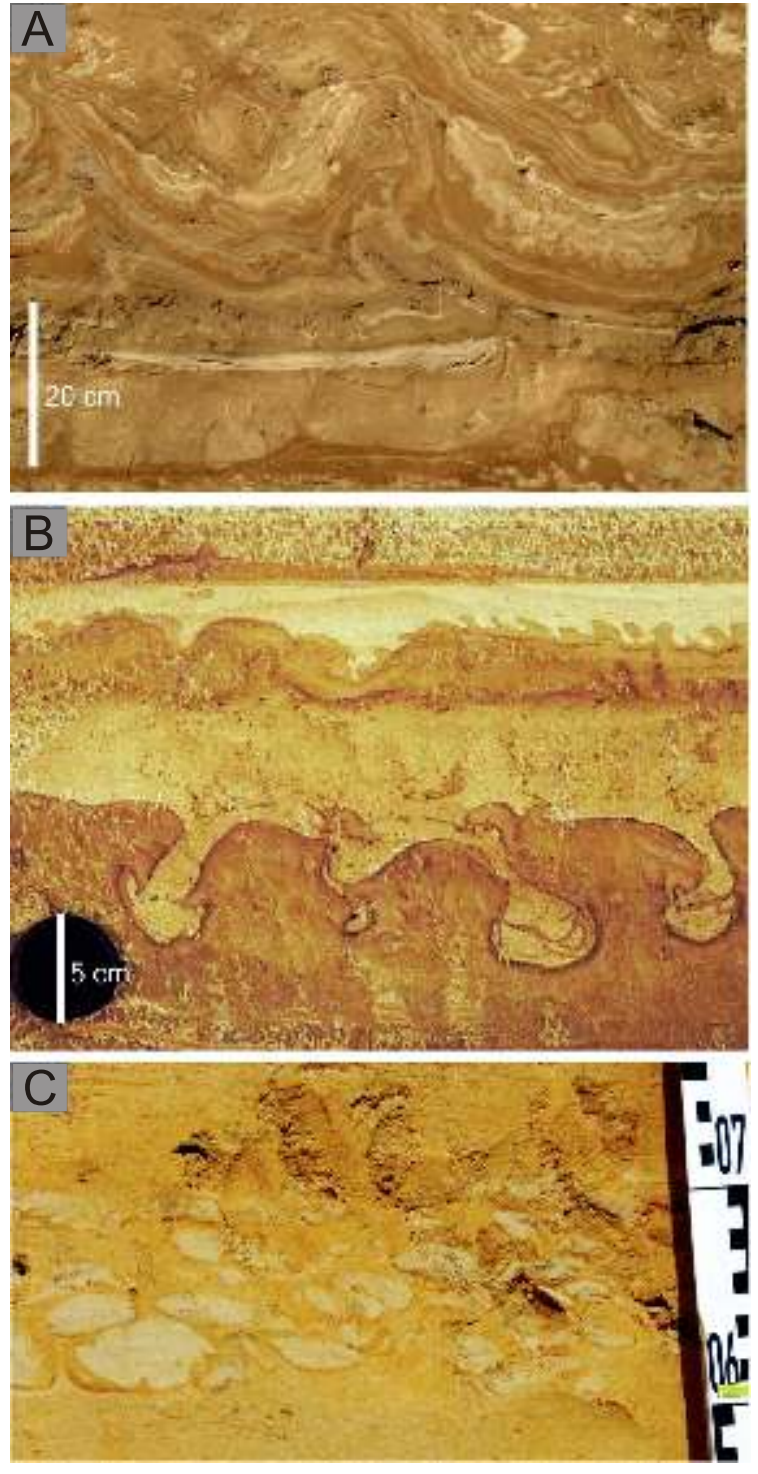

Fig. 9. Vertical extent of deformation structures in a sedimentary succession

A - vertical size of the deformations in seismites may vary but their maximum height is restricted to the thickness of the seismite; most deformation structures in the seismite show this maximum vertical extent; seismite in a quarry near Rakuti (Latvia); B - load structures (so-called "tears") formed in an active layer; the tears tend to extend downward to roughly the same level, which represents the then boundary between the frozen and unfrozen ground; $\mathbf{C}$ - load structures in seismites tend to occur at different heights, either or not being concentrated at specific levels; if several levels with such structures are present, this is commonly due to a series of earthquakes; Weichselian glaciofluvial sands at Siekierki, NW Poland

- different types of load structures that occur in a single deformed level not coinciding with a sedimentary layer are most commonly periglacial, whereas their occurrence at different levels is evidence for a seismic origin.

\section{HORIZONTAL DISTRIBUTION} OF THE LOAD STRUCTURES

Important properties that can be used as evidence to distinguish cryoturbations from seismically-induced deformations are their geometry and horizontal distribution in the deformed layer.

Load structures formed due to liquefaction of sediments with a reversed density gradient exposed to periglacial conditions were described first only less than forty years ago (Vandenberghe and Van den Broek, 1982; Vandenberghe, 1988). Periglacial load structures often tend to show more or less similar horizontal distances between successive load casts (Fig. 10A). It is as yet not clear whether this is a result of the regular polygonal patterns of deformations that tend to develop under periglacial conditions (Van Vliet-Lanoë et al., 2004; French, 2007). The regularity might in this case be caused by the presence of initial cracks (e.g., frost fissures, a pre-existing polygonal crack pattern or desiccation cracks), followed by oversaturated conditions that facilitate loading. The cracks act as weakness zones through which sediment moves upward, eventually forming structures that may in some respects resemble the pillar structures described in numerous publications as a kind of load structures, but that are ascribed to frost heave rather than to loading (Van Vliet-Lanoë et al., 2004; Vandenberghe, 2013); simultaneously, however, the sediment in the upper part of the active layer might sink into the underlying sediment, forming load casts (cf. Vandenberghe, 2013, 2016). Not all these structures are necessarily connected to permafrost: some may be due to deep seasonal frost penetration (e.g., French and Goździk, 1988; Krzyszkowski, 1990; Kasse et al., 1998; Petera-Zganiacz, 2016). In this case, the horizontal pattern of the load structures represents a cell-like polygon network.

It should be kept in mind, however, that load structures are not always the cause of upward push of sediment between them, because the causal relationship may also be the opposite: if some diapirism takes place, the sediments in between two diapirs necessarily form subsiding pockets. Since diapirs or upward intrusions may follow a regular pattern (see, for instance, Anketell et al., 1969, 1970), the "pockets" in between them will consequently also be found at regular distances. This is not only known from halokinesis (Mattauer, 1973; Jackson, 1987), but also from lacustrine sediments (Talbot and Allen, 1996). The situation is more clear in the case of seismically-induced load structures: they are irregular, and their widths and heights are commonly variable over commonly large lateral distances (Van Loon, 2009; Alsop and Marco, 2011; Van Loon and Maulik, 2011; Brandes et al., 2012; Tian et al., 2016) although the distance may be limited by the presence of a sedimentary body that is insufficiently susceptible to mobilization (Moretti and Van Loon, 2014), for instance in the form of a fan (see Pisarska-Jamro y and Woźniak, 2019). The farther away from the epicentre, the more decreases the complexity of seismic load structures; pseudonodules become therefore less frequent with increasing distance from the epicentre, as pseudonodules represent a further developmental stage than simple load casts (cf. Owen, 2003). The lack of regular patterns in seismically-induced load structures (Fig. 10B) must be ascribed to the absence or irregular spatial distribution of pre-existing cracks and to irregularities within the sediment. If a sedimentary succession with a polygonal network of cracks, developed due to periglacial conditions, is affected by a seismic shock, the cracks 

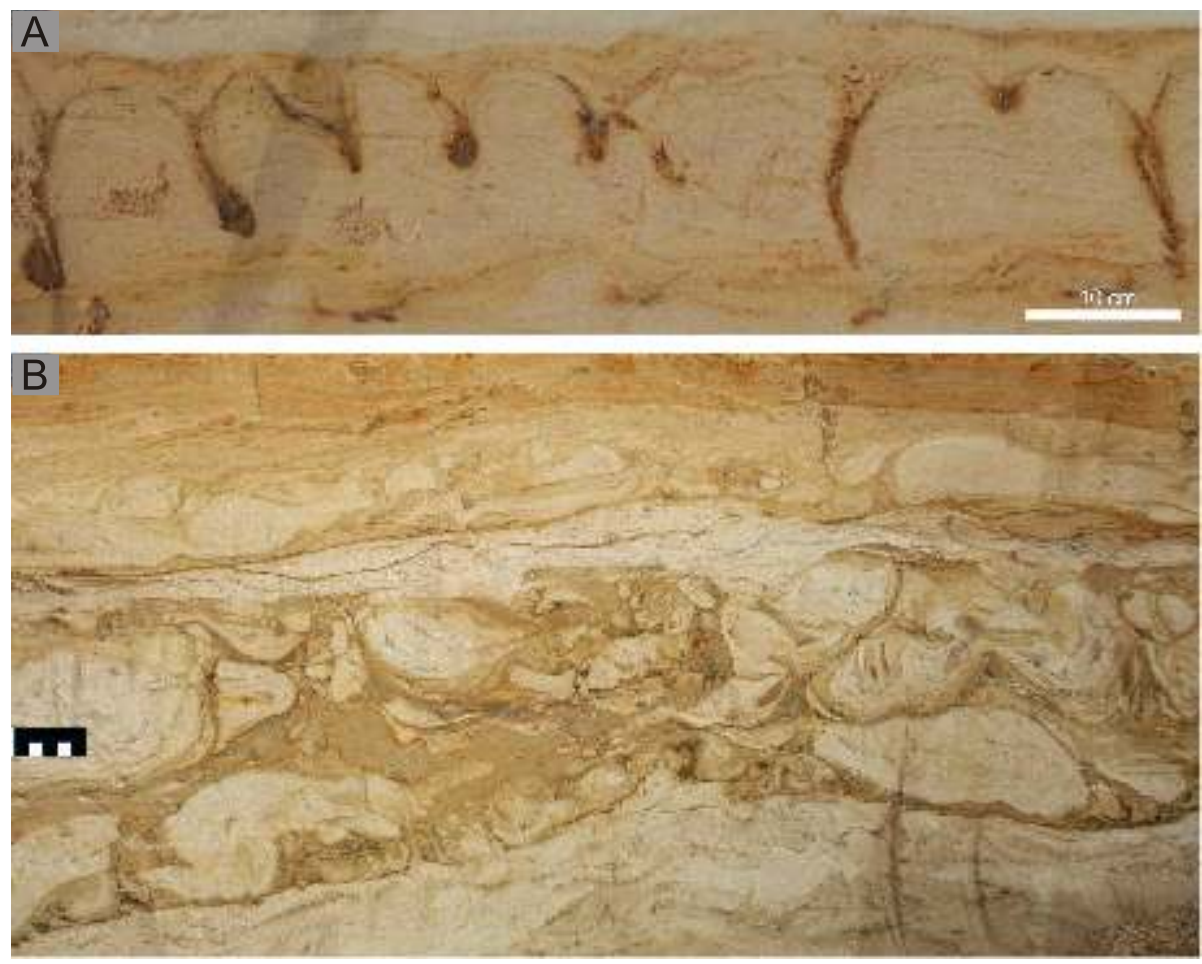

Fig. 10. Regularity of deformation structures

A - periglacial load structures tend to show more or less equal mutual horizontal distances, possibly due to development in zones of weakness such as filled-up frost cracks; Valmiera site, NE Latvia (extended figure; see Van Loon et al., 2016); B - horizontal distances between adjoining load structures in seismites tend to be irregular; seismites near Baltmuiza, Latvia

do - according to the available data from fieldwork - not influence the horizontal distribution of newly formed load structures. This must be ascribed to the fact that a seismite is deformed in its entirety.

The seismically-induced temporary increase of the porewater pressure during passage of a shock wave causes the liquefied layer to be subjected to hydraulic break-throughs. It is noteworthy is this context that loaded "pockets" may result from shock-wave induced upward directed intrusions of fluidized sediment, just like in the case of upward movement of sediment through the regularly spaced cracks formed in a periglacial setting (see above). This has been described from numerous areas where sufficiently strong earthquakes occurred (e.g., Vanneste et al., 1999, 2001; Vanneste and Verbeeck, 2001; Houtgast et al., 2003, 2005; Lafuente et al., 2008; Van Loon and Pisarska-Jamro y, 2014), but there are no clear indications for regular mutual distances between either these intrusions or the load structures in between.

The horizontal distribution of load structures thus provides some evidence for the periglacial or seismic setting in the following way:

- if the horizontal distribution of the load structures is regular, they are most commonly periglacial, whereas a chaotic horizontal distribution is more commonly evidence for a seismic origin;
- if the load structures occur laterally over hundreds of metres, showing gradual horizontal changes in their complexity, they are most likely seismic in origin.

INTERNAL

\section{STRUCTURE OF LOAD STRUCTURES}

Loading is a process that, as explained above, stops when the resistance by the underlying liquefied layer equals the force exerted by the weight of the liquefied overlying, denser layer. Consequently, loading is in principle a process that will not repeat. Even if conditions change, repeated loading at the same place is unlikely. Yet, it is not uncommon that deformed load structures occur, occasionally with load casts that deform earlier formed load casts. This must be ascribed to new events that cause renewed (and more intense) liquefaction than before. Such successive phases of loading are, as a rule, difficult to reconstruct precisely, independent of whether seismic activity or periglacial processes are responsible, so the precise genesis of such multi-phase load structures is commonly difficult (see Vandenberghe et al., 2016). There is, however, one exception: multi-phase load casts can relatively easily originate in a seismically-induced setting because earthquakes tend to be followed by aftershocks. Since these aftershocks are caused by earthquakes that have commonly different magnitudes, the resulting seismic shock waves may cause different degrees of liquefac- 


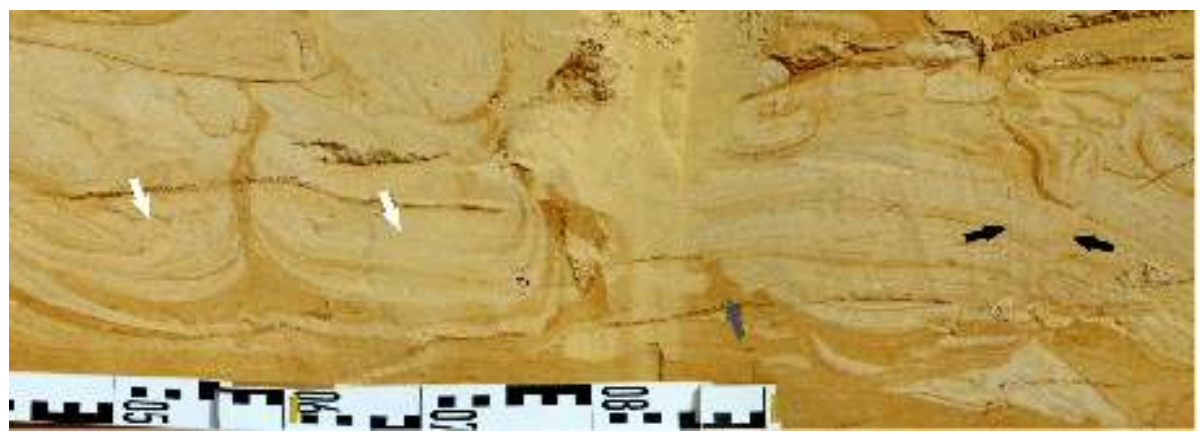

Fig. 11. Detail of a seismite, showing several types of soft-sediment deformation structures closely together, indicating brittle behaviour, liquefaction and fluidization (loading marked by white arrows, injection by grey arrow, and faults by black arrows); Siekierki, NW Poland (see also Van Loon and Pisarska-Jamro y, 2014)

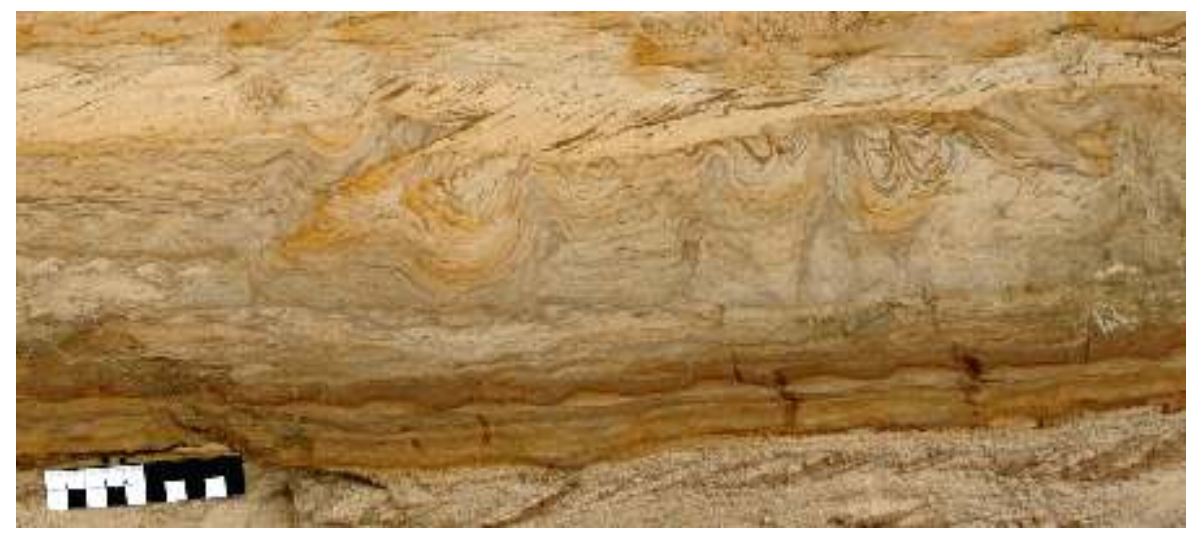

Fig. 12. Truncated deformations of a seismite due to erosion of the topmost part of the succession; Baltmuiza, Latvia

tion, and commonly also different types of deformation (Fig. 11). Moreover, glaciolacustrine sediments that are deformed by a seismic shock may become abraded by wave activity. Truncation is therefore a common feature of seismites (Fig. 12), and the seismite may subsequently become covered by a new layer of glaciolacustrine sediment before a next shock occurs that deforms the earlier originated SSDS. Particularly loading that may thus result can easily deform load casts formed during an earlier earthquake. This explains why seismically-deformed sediments often show load casts within load casts (Fig. 13), or load casts that are deformed by younger load casts. This process may even be repeated several times, so that multi-phase load structures can be formed. Such multi-phase load casts are characterized by internal laminations that are not all parallel to each other, but that deform the lamination of an older generation of load casts.

Pseudonodules may, obviously, also form during a single loading phase or during several phases. For the same reason as mentioned above, it is unlikely that stacked levels of pseudonodules, which are common in seismites (Fig. 14), may develop due to periglacial activity, although this cannot be fully excluded. It is much more likely, however, for seismically-induced specimens. In the case of a series of aftershocks, each series of pseudonodules formed after a specific earthquake tends to occur at a particular level in the deformed layer, whereas they tend to occur in the case of a periglacial origin on the bottom of the active layer, thus creating a single pseudonodule-rich level.
The following characteristics of the internal structure can consequently help to interpret the trigger mechanism of load structures:

- if all internal laminations of a load structure follow the outer boundary more or less precisely, the origin may be either periglacial or seismic, but if the lamination is irregularly deformed, the origin is probably seismic;

- if the load structures show truncations and other irregularities that indicate a multi-phase deformation, their origin is most commonly seismic;

- if levels with pseudonodules occur at different depth within the deformed layer, there origin is most commonly seismic, whereas they are most commonly periglacial if almost all pseudonodules are concentrated in one level of restricted thickness.

\section{DISCUSSION}

Load structures can be formed due to several processes; these can act under numerous conditions, including periglacial and seismic ones. Consequently, the presence of load structures is not diagnostic for either setting. Moreover, sediments affected by a seismic shock can later become exposed to periglacial conditions. On the other hand, sediments with load structures formed due to periglacial processes can become affected by seismic shocks (e.g., Van Vliet-Lanoë et al., 2004; 


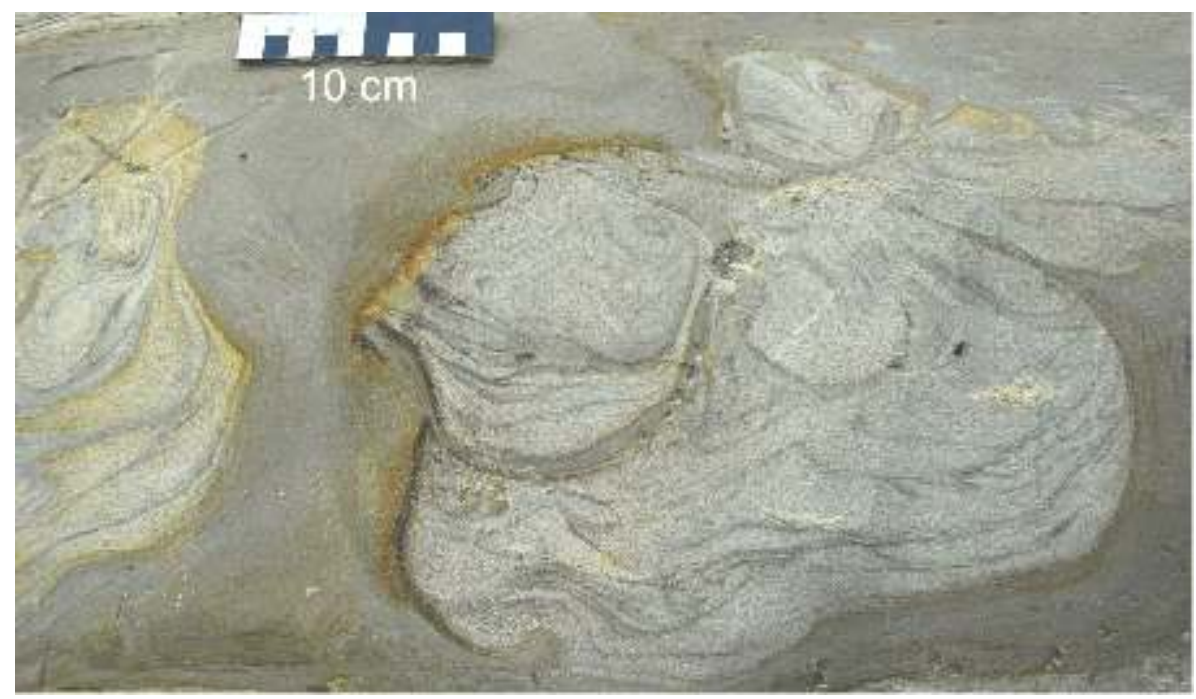

Fig. 13. Load casts within load casts are strong evidence of a seismic origin, as they reflect most probably successive liquefaction phases caused by an earthquake and aftershocks; Dyburiai, NW Lithuania (see Pisarska-Jamro y et al., 2018b)

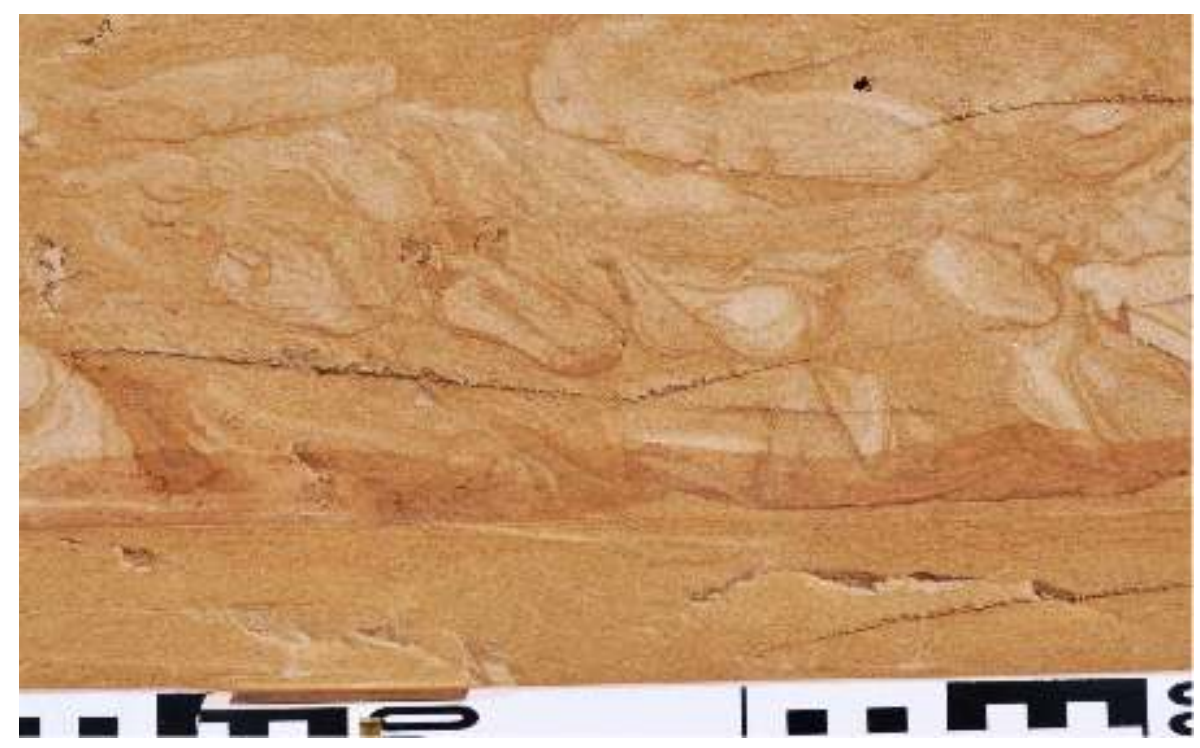

Fig. 14. Series of pseudonodules, roughly arranged at different levels

This is strong evidence for a seismic origin; pseudonodules of seismic origin in Siekierki in NW Poland (Van Loon and Pisarska-Jamro y, 2014)

Alexeev et al., 2014; Vandenberghe et al., 2016). Obviously, successive deformation phases due to both periglacial processes and seismic activity are also very well possible. Furthermore, the original load-structure geometry can be modified later, for instance by lateral stresses related to slope processes, water currents, a hydraulic gradient or glaciotectonics (Dasgupta, 1998; Moretti et al., 2001).

Consequently, it is, as a rule, not possible to state that load structures are beyond any doubt due to either of these trigger mechanisms, unless one of these mechanisms can be ruled out with certainty. Pleistocene sediments in the coastal lowlands of tropical areas, for instance, will not have been affected by periglacial processes, but Pleistocene glaciogenic sediments in intracratonic areas that are tectonically stable will al- most certainly have been affected by periglacial processes. This complexity makes a reliable analysis of the triggers of load structures much more complex, but a step-by-step approach may eventually well lead to a conclusion which evidence is the most convincing.

The mechanisms and processes that induced load structures must therefore most commonly be interpreted on the basis of circumstantial evidence. The most important parameters in this respect seem to be the horizontal and vertical distribution of these SSDS within deformed units, and their internal structure. The interpretation made on such a basis can be supported by the occurrence or absence of specific indicative deformations such as mud volcanoes, sand boils, clastic dykes and water-escape pipes (Rossetti, 1999; Van Vliet-Lanoë et al., 2004; 
Vandenberghe et al., 2016) in seismic settings, and ice-wedge pseudomorphs and frost-cracks in periglacial settings (French, 2007). However, all these aspects can only make a periglacial or seismic origin more likely (or unlikely), but they do, as already mentioned above, not provide definite proof. On the other hand, if all data point into the same direction, it seems scientifically acceptable to consider this as sufficiently strong evidence.

Seismites were recognized only relatively recently (Seilacher, 1984), and their importance was long underestimated. Seismically-induced deformation structures and particularly seismites still receive less attention from Quaternary geologists than desirable, particularly because it has become clear in numerous studies that fluctuations in the position of the large Pleistocene ice sheets induced frequent earthquakes, often of sufficient magnitude to cause seismites.

This is precisely why we hope that our contribution will help Quaternary geologists to consider the possibility of a seismic origin when they investigate soft-sediment deformation struc- tures in periglacially affected areas. The more data about glaciation-related earthquakes become available, the better the insight into the Pleistocene history of the earth will become.

How analysis of load structures and other SSDS can help unravel the various deformational processes can best be illustrated on the basis of a case history. For the purpose, we refer to a study of three deformed sedimentary levels within an undeformed glaciolacustrine and glaciofluvial succession (Fig. $15 \mathrm{~A}$ ) exposed in a coastal cliff on Rügen Island (southwestern Baltic Sea). Based on their structural and deformational features, two of the deformed layers could be interpreted as seismites (Fig. 15B) which formed by shock waves resulting from earthquakes due to flexural isostatic response of the Earth's crust as a consequence of the ice load during ice advance, probably due to local re-activation of pre-existing faults. The third deformed level could be interpreted as a result of periglacial processes (Fig. 15C). For more details, the reader is referred to Pisarska-Jamro y et al. (2018a, b, 2019b).
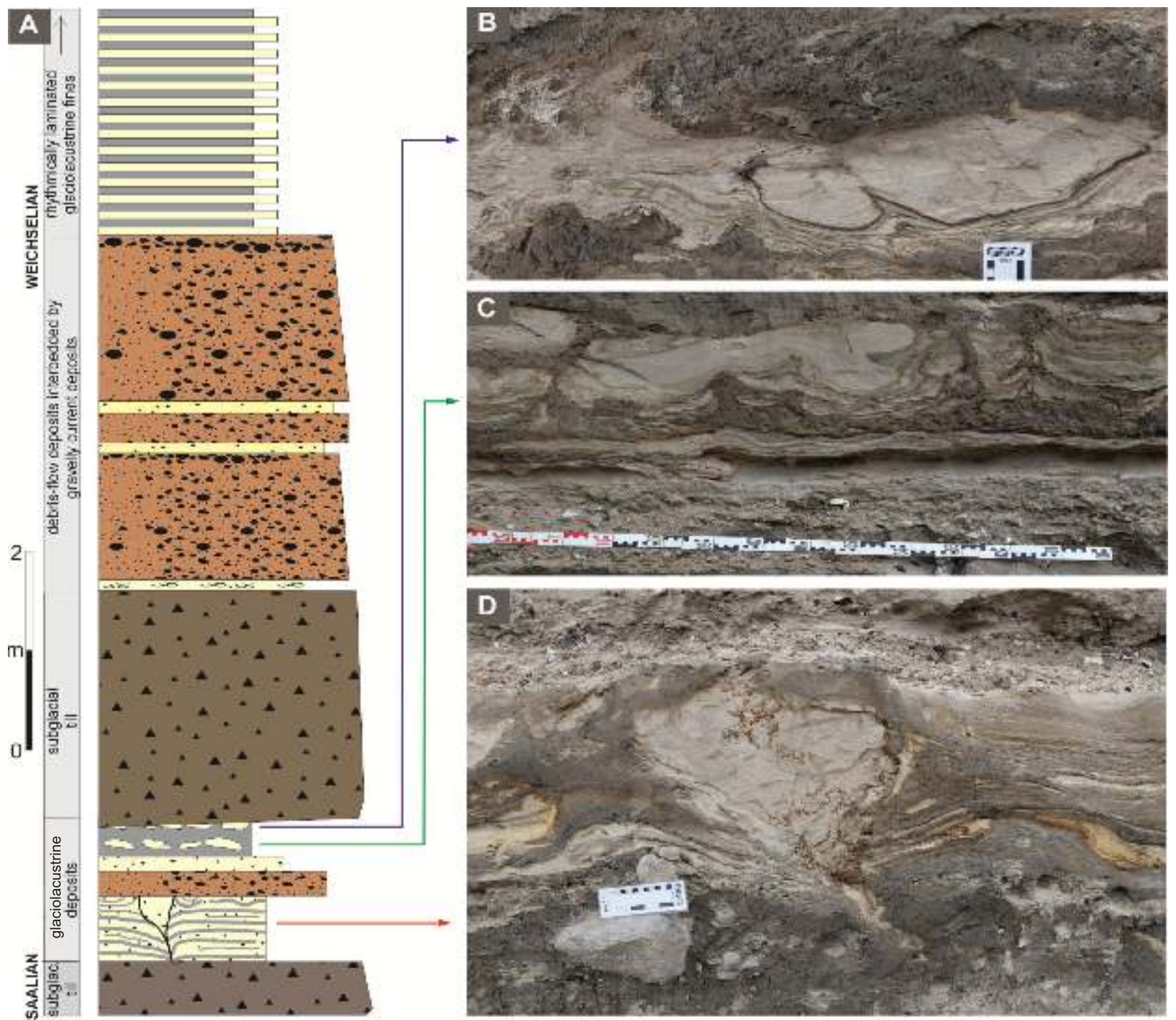

Fig. 15. Sedimentary succession at Dwasieden, NE Germany (see Pisarska-Jamro y et al., 2018a)

A - cliff succession with three deformed sedimentary layers; B, C - details of the two stacked seismites; D - detail of the periglacially deformed layer showing a loaded frost-wedge cast 


\section{CONCLUSIONS}

Diagnostic criteria for the distinction between load structures formed by periglacial processes from those formed by seismicity-related processes do not exist, but the following aspects provide evidence:

1. Periglacially-induced load structures occur commonly close to the sedimentary surface (present or ancient) and are restricted to the (then) active layer, which need not coincide with a sedimentary layer or set of layers. Seismically-induced load structures tend also to occur close to the sedimentary surface (present or ancient) but may also occur at somewhat deeper levels (most commonly up to $5 \mathrm{~m}$ below the surface).

2. Seismically-induced load structures tend to occur, in contrast to periglacial load structures, in well-defined layers (= seismites) with sharp boundaries; in a sedimentary succession, several seismites may be present, either stacked immediately upon each other or separated by undeformed layers. Such vertical alternations of well-defined deformed and non-deformed layers do not originate due to periglacial processes.

3. Periglacially-induced load structures extend to more or less the same depth and can sink into underlying layers with different lithology; if the sediment layers are not horizontal, the load structures may be present all over the exposure to roughly the same depth, independently of whether stratigraphically dif- ferent levels are involved. Seismic load structures occur at all depth within well-defined deformed layers (or sets of layers) that show abundant SSDS over large lateral distances, independent of changes in height of the layer, but they do not (or much less frequently) occur in under- and overlying layers.

4. Seismic load structures tend to show gradual horizontal changes in their size and complexity, whereas periglacial load structures do not.

5. Periglacial load structures may occur in a more or less regular pattern (cell-like polygon network), whereas seismically-induced load structures tend to occur in a less regular pattern, even though cell-like polygons may originate in all systems with unstable density gradients (cf. Alfaro et al., 2010).

6. In periglacial load casts, the internal lamination runs almost always roughly parallel to the outer boundary of the structure. In seismic load casts, complex deformation with truncated lamination may be present due to multi-phase shock-induced deformation.

Acknowledgements. The suggestions by the reviewers M. Moretti and P. Weckwerth have greatly helped to improve the manuscript, for which we are most grateful. The work has been financially supported in the context of the GREBAL project by the National Science Centre Poland No. 2015/19/B/ST10/00661 and National Science Centre Poland No. $2013 / 09 / B / S T 10 / 02118$.

\section{REFERENCES}

Alexeev, S., Alexeeva, L., Kononov, A., 2014. Cryogenic deformation structures in Late Cenozoic unconsolidated sediments of the Tunka Depression in the Baikal rift zone. Permafrost and Periglacial Processes, 25: 117-126.

Alfaro, P., Gibert, L., Moretti, M., García-Tortosa, F.J., Sanz de Galdeano, C., Galindo-Zaldívar, J., López-Garrido. T.C., 2010. The significance of giant seismites in the Plio-Pleistocene Baza palaeo-lake (S Spain). Terra Nova, 22: 172-179.

Allen, J.R.L., 1986. Earthquake magnitude-frequency, epicentral distance, and soft-sediment deformation in sedimentary basins. Sedimentary Geology, 46: 67-75.

Alsop, G.I., Marco, S., 2011. Soft-sediment deformation within seismogenic slumps of the Dead Sea Basin. Journal of Structural Geology, 33: 433-457.

Ambraseys, N.N., 1988. Engineering seismology. Earthquake Engineering and Structural Dynamics, 17: 1-105.

Anketell, J.M., Cegła, J., D ułyński, S., 1969. Unconformable surfaces formed in the absence of current erosion. Geologica Romana, 8: 41-46.

Anketell, J.M., Cegła, J., D ułyński, S., 1970. On the deformational structures in systems with reverse density gradients. Annales de la Société Géologique de Pologne, 40: 3-30.

Belzyt, S., Pisarska-Jamro y, M., 2017. How to study seismites? A review of research methods (in Polish with English summary). Acta Geographica Lodziensia, 106: 171-180.

Brandes, C., Winsemann, J., Roskosch, J., Meinsen, J., Tanner, D.C., Frechen, M., Steffen, H., Wu, P., 2012. Activity along the Osning thrust in central Europe during the Lateglacial: Ice-sheet and lithosphere interactions. Quaternary Science Reviews, 38 49-62.

Dasgupta, P., 1998. Recumbent flame structures in the Lower Gondwana rocks of the Jharia Basin. India - a plausible origin. Sedimentary Geology, 119: 253-261.
Deev, E.V., Zolnikov, I.D., Gus'kov, S.A., 2009. Seismites in Quaternary sediments of southeastern Altai. Russian Geology and Geophysics, 50: 546-561.

D ułyński, S., 1966. Sedimentary structures resulting from convection-like pattern of motions. Annales de la Société Géologique de Pologne, 36: 3-21.

Edelman, C.H., Florschütz, F., Jeswiet, J., 1936. Ueber spätpleistozäne und frühholozäne kryoturbate Ablagerungen in den ostlichen Niederlanden. Verhandelingen Koninklijk Mijnbouwkundig Genootschap voor Nederland en Koloniën, Geologische Serie, 11: 301-360.

French, H., 2007. The Periglacial Environment. John Wiley and Sons Ltd, Chichester.

French, H.M., Goździk, J., 1988. Pleistocene epigenetic and syngenetic frost fissures, Belchatów, Poland. Canadian Journal of Earth Sciences, 25: 2017-2027.

French, H.M., Demitroff, M., Forman, S.L., 2005. Evidence for Late-Pleistocene thermokarst in the New Jersey Pine Barrens (latitude 39-N), eastern USA. Permafrost and Periglacial Processes, 16: 173-186.

French, H.M., Shur, Y.L., 2010. The principles of cryostratigraphy Earth-Science Reviews, 101: 190-206.

Galli, P., 2000. New empirical relationships between magnitude and distance for liquefaction. Tectonophysics, 324: 169-187.

Gruszka, B., Van Loon, A.J., Mokhtari Fard, A., 2016. A fluctuating ice front over an esker near Ryssjön (S Sweden) as a cause of a giant load cast. Sedimentary Geology, 344: 47-56.

Harris, C., Murton, J., Davies, M.C.R., 2000. Soft-sediment deformation during thawing of ice-rich frozen soils: results of scaled centrifuge modelling experiments. Sedimentology, 47: 687-700.

Hoffmann, G., Reicherter, K., 2012. Soft-sediment deformation of Late Pleistocene sediments along the southwestern coast of the Baltic Sea (NE Germany). International Journal of Earth Sciences, 101: 351-363. 
Houtgast, R.F., Van Balen, R.T., Kasse, C., Vandenberghe, J., 2003. Late Quaternary tectonic evolution and postseismic near surface fault displacements along the Geleen Fault (Feldbiss Fault Zone - Roer Valley Rift System, the Netherlands) based on trenching. Netherlands Journal of Geosciences, $\mathbf{8 2}$ 177-196.

Houtgast, R.F., Van Balen, R.T., Kasse, C., 2005. Late Quaternaty evolution of the Feldbiss Fault (Roer Valley Rift System, the Netherlands) based on trenching, and its potential relation to glacial unloading. Quaternary Science Reviews, 24: 491-510.

Jackson, M.P.A., 1987. Salt tectonics. Scientific American, 257: 70-79.

Kasse, C., Huijzer, A., Krzyszkowski, D., Bohncke, S., Coope G., 1998. Weichselian Late Pleniglacial and Late-Glacia depositional environments, Coleoptera and periglacial climatic records from central Poland (Bełchatów). Journal of Quaternary Science, 13: 455-469.

Koç Taşgin, C.K., Türkmen, I., 2009. Analysis of soft-sediment deformation structures in Neogene fluvio-lacustrine deposits of Çayba - 2 Formation, eastern Turkey. Sedimentary Geology, 218: $16-30$.

Konrad, J.M., 2005. Estimation of the segregation potential of fine-grained soils using the frost heave response of two reference soils. Canadian Geotechnical Journal, 42: 38-50.

Krzyszkowski, D., 1990. Middle and Late Weischelian stratigraphy and paleoenvironments in central Poland. Boreas, 19: 333-350.

Kuenen, Ph.H., 1953. Significant features of graded bedding. AAPG Bulletin, 37: 1044-1066.

Lafuente, P., Rodríguez-Pascua, M.A., Simón, J.L., Arlegui, L.E., Liesa, C.L., 2008. Seismites in Pliocene and Pleistocene deposits of the Teruel Graben (in Spanish with English summary). Revista de la Sociedad Geológica de Espańa, 21: 133-149.

Lowe, D.R., 1976. Subaqueous liquefied and fluidized flows and their deposits. Sedimentology, 23: 285-308.

Macar, P., 1948. Les pseudo-nodules du Famennien et leur origine. Annales de la Société Géologique de Belgique, 72: 47-74.

Marco, S., Agnon, A., 1995. High-resolution stratigraphy reveals repeated earthquake faulting in the Masada Fault Zone, Dead Sea Transform. Tectonophysics, 408: 101-112.

Marks, L., Nitychoruk, J., Majecka, A., Hrychanik, M., 2018. Re vised limit of the Saalian ice sheet in central Europe. Quaternary International, 478: 59-74.

Mattauer, M., 1973. Les déformations des Matériaux de l'Écorce Terrestre. Hermann (Paris): 493 pp.

Moretti, M., Alfaro, P., Caselles, O., Canas, J.A., 1999. Modelling seismites with a digital shaking table. Tectonophysics, 304 369-383.

Moretti, M., Soria, J.M., Alfaro, P., Walsh, N., 2001. Asymmetrical soft-sediment deformation structures triggered by rapid sedimentation in turbiditic deposits (Late Miocene, Guadix Basin, southern Spain). Facies, 44: 283-294.

Moretti, M., Van Loon, A.J., 2014. Restrictions to the application of 'diagnostic' criteria for recognizing ancient seismites. Journal of Palaeogeography, 3: 162-173.

Moretti, M., Alfaro, P., Owen, G. eds., 2016. The environmenta significance of soft-sediment deformation structures: key signatures for sedimentary and tectonic processes. Sedimentary Geology, 344: 1-408.

Morsilli, M., Bucci, M.G., Gliozzi, E., Lisco, S., Moretti, M., 2020. Sedimentary features influencing the occurrence and spatial variability of seismites (late Messinian, Gargano Promontory, southern Italy). Sedimentary Geology, 401: 105628.

Mörner, N.A., 1990. Glacial isostasy and long-term crustal movements in Fennoscandia with respect to lithospheric and asthenospheric processes and properties. Tectonophysics, 176: $13-24$

Mörner, N.A., 1991. Intense earthquakes and seismotectonics as a function of glacial isostasy. Tectonophysics, 188: 407-410.

Murton, J.B., French, H.M., 1993. Thermokarst involutions, summer island, Pleistocene Mackenzie delta, western Canadian arctic. Permafrost and Periglacial Processes, 4: 217-229.
Obermeier, S.F., 1996. Use of liquefaction-induced features for paleoseismic analysis - an overview of how seismic liquefaction features can be distinguished from other features and how their regional distribution and properties of source sediment can be used to infer the location and strength of Holocene paleoearthquakes. Engineering Geology, 44: 1-76.

Ogino, Y., Matsuoka, N., 2007. Involutions resulting from annual freeze-thaw cycles: a laboratory simulation based on observations in northeastern Japan. Permafrost and Periglacial Processes, 18: 323-335.

Owen, G., 2003. Load structures: gravity-driven sediment mobilization in the shallow subsurface. In: Subsurface Sediment Mobilization (eds. P. Van Rensbergen, R.R. Hillis, A.J. Maltman and C.K. Morley): 21-34. Geological Society, London.

Owen, G., Moretti, M., 2011. Identifying triggers for liquefaction-induced soft-sediment deformation in sands. Sedimentary Geology, 235: 141-147.

Owen, G., Moretti, M., Alfaro, P., 2011. Recognising triggers for soft-sediment deformation: current understanding and future directions. Sedimentary Geology, 235: 133-140.

Petera-Zganiacz, J., 2016. Determinants of differentiation of the Late Vistulian involutions in the north-western part of the Łódź region (in Polish with English summary). Acta Universitatis Lodziensis Folia Geographica Physica, 15: 45-54

Pisarska-Jamro y, M., Woźniak, P.P., 2019. Debris flow and glacioisostatic-induced soft-sediment deformation structures in a Pleistocene glaciolacustrine fan: the southern Baltic Sea coast, Poland. Geomorphology, 326: 225-238.

Pisarska-Jamro y, M., Belzyt, S., Börner, A., Hoffmann, G., Hüneke, H., Kenzler, M., Obst, K., Rother, H., Van Loon, A.J. 2018a. Evidence from seismites for glacio-isostatically induced crustal faulting in front of an advancing land-ice mass (Rügen Island, SW Baltic Sea). Tectonophysics, 745: 338-348.

Pisarska-Jamro y, M., Belzyt, S., Bitinas, A., Jusienè, A., Damušytè, A., Woronko, B., 2018b. A glaciolacustrine succession (Dyburiai outcrop, NW Lithuania) with numerous deformed layers sandwiched between undeformed layers. In: Soft-sediment deformation structures and palaeoseismic phenomena in the South-eastern Baltic Region (eds. M. Pisarska-Jamro y and A. Bitinas): 43-48. Lithuanian Geological Survey, Lithuanian Geological Society, Vilnius.

Pisarska-Jamro y, M., Belzyt, S., Bitinas, A., Jusienè, A., Woronko, B., 2019a. Seismic shocks, periglacial conditions and glaciotectonics as causes of the deformation of a Pleistocene meandering river succession in central Lithuania. Baltica, 32: 63-77.

Pisarska-Jamro y, M., Belzyt, S., Börner, A., Hoffmann, G., Hüneke, H., Kenzler, M., Obst, K., Rother, H., Steffen, H., Steffen, R., Van Loon, A.J., 2019b. The sea cliff at Dwasieden: soft-sediment deformation structures triggered by glacial isostatic adjustment in front of the advancing Scandinavian Ice Sheet. Deuqua Special Publications, 2: 61-67.

Rana, N., Sati, S.P., Sundriyal, Y., Juyal, N., 2016. Genesis and implication of soft-sediment deformation structures in high-energy fluvial deposits of the Alaknanda Valley, Garhwal Himalaya, India. Sedimentary Geology, 344: 263-276.

Rossetti, D.F., 1999. Soft-sediment deformation structures in late Albian to Cenomanian deposits, San Luìs Basin, northern Brazil: evidence for paleoseismicity. Sedimentology, 46: 1065-1081.

Seilacher, A., 1984. Sedimentary structures tentatively attributed to seismic events. Marine Geology, 55: 1-12.

Shrock, R.R., 1948. Sequence in Layered Rocks - a Study of Features and Structures Useful for Determining Top and Bottom or Order of Succession in Bedded and Tabular Rock Bodies. McGraw-Hill (New York).

Superson, J., Gębica, P., Brzezińska-Wójcik, T., 2010. The origin of deformation structures in periglacial fluvial sediments of the Wisłok valley, southeast Poland. Permafrost and Periglacial Processes, 21: 301-314.

Talbot, M.R., Allen, P.A., 1996. Lakes. In: Sedimentary environments - Processes, Facies and Stratigraphy (ed. H.G. Reading): 83-124. Blackwell (Malden/Oxford/Carlton). 
Tian, H.S., Van Loon, A.J., Wang, H.L., Zhang, S.H., Zhu, J.W., 2016. Seismites in the Dasheng Group: New evidence of strong tectonic and earthquake activities of the Tanlu Fault Zone. Science China, Earth Science, 59: 601-618.

Vandenberghe, J., 1988. Cryoturbations. In: Advances in Periglacial Geomorphology (ed. M.J. Clark): 179-198. John Wiley and Sons (Chichester).

Vandenberghe, J., 2009. Comment to 'Zur Struktur und Entstehung von Eiskeil-Grossformen in Lieth/Elmshorn (Schleswig-Holstein)' by A. Grube, 2007 (Quaternary Science Journal 56, 283-294). Journal of Quaternary Science, 58: 107-109.

Vandenberghe, J., 2013. Cryoturbation structures. In: The Encyclopedia of Quaternary Science (ed. S.A. Elias): 430-435. Amsterdam, Elsevier.

Vandenberghe, J., Van den Broek, J., 1982. Weichselian convolution phenomena and processes in fine sediments. Boreas, 11 299-315.

Vandenberghe, J., Wang, X., Vandenberghe, D., 2016. Very large cryoturbation structures of Last Permafrost Maximum age at the foot of the Qilian Mountains (NE Tibet Plateau, China). Permafrost and Periglacial Processes, 27: 138-143.

Vandenberghe, J., Wang, X., Vandenberghe, D., 2017. Comment on 'Very large cryoturbation structures of Last Permafrost Maximum age at the foot of Qilian Mountains (NE Tibet plateau, China): a discussion' by Stuart A. Harris, Huijun Jin and Ruixia $\mathrm{He}$ in PPP. Permafrost and Periglacial Processes, 28: 763-766.

Van Loon, A.J. ed., 2009. Soft-sediment deformation structures in siliciclastic sediments: an overview. Geologos, 15: 3-55.

Van Loon, A.J., 2014. Seismites and their soft-sediment deformation structures. Geologos, 20: 61-166.

Van Loon, A.J., Maulik, P., 2011. Abraded sand volcanoes as a tool for recognizing paleoearthquakes, with examples from the Cisuralian Talchir Formation near Angul (Orissa, eastern India). Sedimentary Geology, 238: 145-155.
Van Loon, A.J., Pisarska-Jamro y, M., 2014. Sedimentological evidence of Pleistocene earthquakes in NW Poland induced by glacio-isostatic rebound. Sedimentary Geology, 300: 1-10.

Van Loon, A.J., Wiggers, A.J., 1976. Metasedimentary "graben" and associated structures in the lagoonal Almere Member (Groningen Formation, the Netherlands). Sedimentary Geology, 16: 237-254.

Van Loon, A.J., Pisarska-Jamro y, M., Nartišs, M., Krievāns, M., Soms, J., 2016. Seismites resulting from high-frequency, high-magnitude earthquakes in Latvia caused by Late Glacial glacio-isostatic uplift. Journal of Palaeogeography, 5: 363-380.

Vanneste, K., Verbeeck, K., 2001. Paleoseismological analysis of the Rurrand fault near Jülich, Roer Valley Graben, Germany: coseismic or aseismic faulting history? Netherlands Journal of Geosciences, 89: 155-169.

Vanneste, K., Meghraoui, M., Camelbeeck, T., 1999. Late Quaternary earthquake-related soft-sediment deformation along the Belgian portion of the Feldbiss Fault, lower Rhine Graben system. Tectonophysics, 309: 57-79.

Vanneste, K., Verbeeck, K., Camelbeeck, T., Paulissen, E., Meghraoui, M., Renardy, F., Jongmans, D., Frechen, M., 2001. Surface rupturing history of the Bree fault scarp, Roer Valley Graben. Evidence for six events since the late Pleistocene. Journal of Seismology, 5: 329-359.

Van Vliet-Lanoë, B., Magyari, A., Meilliez, F., 2004. Distinguishing between tectonic and periglacial deformation of Quaternary continental deposits in Europe. Global and Planetary Change, 43: 103-127.

Van Straaten, L.M.J.U., 1954. Sedimentology of recent tidal $X$ at deposits and the Psammites du Condroz (Devonian). Geologie en Mijnbouw, 16: 25-47.

Wu, P., Johnston, P., 2000. Can deglaciation trigger earthquakes in N. America? Geophysical Research Letters, 27: 1323-1326. 